\title{
The genus Neoaquastroma is widely distributed; a taxonomic novelty, N. cylindricum sp. nov. (Parabambusicolaceae, Pleosporales) from Guizhou, China
}

\author{
Samarakoon $\mathrm{MC}^{1,2,3,4}$, Wanasinghe $\mathrm{DN}^{5,6}$, Liu $\mathrm{JK}^{2,3}$, Hyde $\mathrm{KD}^{1,5 *}$ and \\ Promputtha $\mathrm{I}^{4,7}$
}

${ }^{1}$ Center of Excellence in Fungal Research, Mae Fah Luang University, Chiang Rai 57100, Thailand

${ }^{2}$ School of Life Science and Technology, University of Electronic Science and Technology of China, Chengdu 611731, P.R. China

${ }^{3}$ Guizhou Key Laboratory of Agricultural Biotechnology, Guizhou Academy of Agricultural Sciences, Guiyang 550006, P.R. China

${ }^{4}$ Department of Biology, Faculty of Science, Chiang Mai University, Chiang Mai 50200, Thailand

${ }^{5}$ Key Laboratory for Plant Diversity and Biogeography of East Asia, Kunming Institute of Botany, Chinese Academy of Sciences, 132, Lanhei Road, Kunming 650201, P.R. China

${ }^{6}$ World Agro Forestry Centre, East and Central Asia, 132, Lanhei Road, Kunming 650201, P.R. China

${ }^{7}$ Center of Excellence in Bioresources for Agriculture, Industry and Medicine, Faculty of Science, Chiang Mai University, Chiang Mai 50200, Thailand

Samarakoon MC, Wanasinghe DN, Liu JK, Hyde KD, Promputtha I 2019 - The genus Neoaquastroma is widely distributed; a taxonomic novelty, $N$. cylindricum sp. nov. (Parabambusicolaceae, Pleosporales) from Guizhou, China. Asian Journal of Mycology 2(1), 235244, Doi 10.5943/ajom/2/1/14

\begin{abstract}
Neoaquastroma is a saprobe on dead twigs, characterized by having immersed, globose to sub-globose ascomata, short papillate ostiole, a thin peridium with cells of textura angularis, branched, septate pseudoparaphyses, cylindrical clavate, short pedicellate asci with an ocular chamber, overlapping biseriate to triseriate, ellipsoidal to sub-fusiform, hyaline, multi-septate ascospores with a distinct mucilaginous sheath. They have a coelomycetous asexual morph with uniloculate, pycnidial conidiomata, enteroblastic, phialidic, integrated, hyaline, oblong conidiogenous cells, broad-oblong to oval, hyaline, aseptate conidia. Earlier they were only reported from Thailand. In this study, we found another new species to the genus (Neoaquastroma cylindricum) from Guizhou, China as the fourth species based on both morpho-phylo evidences. Neoaquastroma cylindricum is distinguished from other Neoaquastroma species by its cylindricclavate asci and comparatively small ascospores with a smaller number of transverse septa. Maximum parsimony, maximum likelihood and Bayesian inference analyses of combined LSUSSU-ITS-tef1 sequence matrix confirmed its placement within Parabambusicolaceae with a close affinity to Neoaquastroma krabiense. The new taxon is compared with other species in Neoaquastroma and comprehensive descriptions, illustrations (including DNA based phylogenies) and a synopsis table for relevant species are provided.
\end{abstract}

Keywords - 1 new species - Dothideomycetes - multi-gene - phylogeny - taxonomy 


\section{Introduction}

Exploration of novel fungal species and placing them in their higher ranks is at a rapid rate during the last few decades mainly due to the advancement of molecular techniques. Those novel discoveries are dominated by phylum Ascomycota Caval.-Sm. with $68 \%$ of the total novel species in 2017 (Willis 2018). Among the ascomycetous classes, Dothideomycetes O.E. Erikss. \& Winka is highly diversified and the highest numbers of taxa are accounted (Liu et al. 2017, Wijayawardene et al. 2017, 2018). Pleosporales Luttrell ex M.E. Barr is one of the orders in Dothideomycetes, which is cosmopolitan and hosting a large number of novel species and higher ranks with a high species diversity (Hyde et al. 2016, 2017, 2018, 2019, Crous et al. 2018, 2019, Wanasinghe et al. 2018, Phookamsak et al. 2019).

Parabambusicolaceae Kaz. Tanaka \& K. Hiray. (Massarineae; Pleosporales) was introduced by Tanaka et al. (2015) to accommodate the genera Aquastroma Kaz. Tanaka \& K. Hiray., Parabambusicola Kaz. Tanaka \& K. Hiray., Multiseptospora Phook. \& K.D. Hyde and two unnamed Monodictys S. Hughes species. The family is characterized by pseudothecioid ascomata with or without stromatic tissues, papillate to apapillate ostioles, clavate to fusiform asci and hyaline or brown phragmospores bearing sexual morph and sporodochial or monodictys-like asexual morph (Ariyawansa et al. 2015, Liu et al. 2015, Tanaka et al. 2015, Li et al. 2016, Wanasinghe et al. 2017a, 2017b, Phukhamsakda et al. 2018). At present, there are six accepted genera in the Parabambusicolaceae viz. Aquastroma, Multilocularia Phook. et al., Multiseptospora, Neoaquastroma Wanas. et al., Parabambusicola and Pseudomonodictys Doilom et al. (Wijayawardene et al. 2017, 2018, Phukhamsakda et al. 2018).

Wanasinghe et al. (2017a) introduced the genus Neoaquastroma typified by N. guttulatum Wanas. et al., which was collected on a dead twig from Thailand. The genus is distinguished from the other related genera by its fully immersed pseudothecia and in well-supported multi-gene based phylogenies (Phukhamsakda et al. 2018). Recently, Phukhamsakda et al. (2018) introduced two new species viz. $N$. bauhiniae C. Phukhams. \& K.D. Hyde and N. krabiense C. Phukhams. \& K.D. Hyde from Thailand while increasing the total number of Neoaquastroma species up to three. This study provides the morpho-molecular evidence of the new Neoaquastroma species, $N$. cylindricum collected from Guizhou, China as the first record outside Thailand.

\section{Materials \& Methods}

\section{Collection, isolation and morphological studies}

Dead twigs of different landscaping plants were collected from Guizhou Academy of Agricultural Sciences (GZAAS) premises, Guiyang, Guizhou, China during May-August 2018. The specimens were placed into paper bags and dried under room temperature for two days. External examinations were made through the stereomicroscope (SteREO Discovery v8) attached with Axio Cam ERc5s while microscopic photography was made by using Nikon ECLIPSE Ni-U compound microscope (Nikon, Tokyo, Japan) attached with Canon EOS 600D camera (Canon Inc., Tokyo, Japan). Measurements were made with the Tarosoft (R) Image Frame Work program and images used for figures were processed with Adobe Photoshop CS6 software (Adobe Systems Inc).

Pure cultures were obtained from single ascospore isolation on potato dextrose agar (PDA) in double-distilled water following Chomnunti et al. (2014) and Samarakoon et al. (2018). Germinated ascospores were transferred on PDA aseptically and incubated at $25-30{ }^{\circ} \mathrm{C}$ for $4-6$ weeks with frequent observations. The type specimens were deposited in the Mae Fah Luang University Herbarium (MFLU), Chiang Rai, Thailand and the Herbarium of Cryptogams Kunming Institute of Botany Academia Sinica (HKAS), Chinese Academy of Sciences, Kunming, China. The ex-type culture was deposited in the Culture Collection at Mae Fah Luang University (MFLUCC). The new taxon was linked with Facesoffungi and Index Fungorum databases as explained in Jayasiri et al. (2015) and Index Fungorum (http://www.indexfungorum.org). 


\section{DNA extraction, PCR amplification and sequencing}

DNA was extracted from fresh mycelium by using total DNA extraction kits according to the manufacturer's instructions (Sangon Biotech (Shanghai) Co. Ltd. China). Primers ITS5/ITS4, NS1/NS4 (White et al. 1990), LR0R/LR5 (Vilgalys \& Hester 1990), EF1-983F/EF1-2218R (Carbone \& Kohn 1999) and Bt2a/Bt2b (Glass \& Donaldson 1995) were used to amplify the DNA sequences of the internal transcribed spacers (ITS1-5.8S-ITS2), the partial 18S small subunit rDNA (SSU), the partial 28S large subunit rDNA (LSU), partial translation elongation factor-1 $\alpha$ (tef1) and partial $\beta$-tubulin (tub2) respectively. The total volume of $25 \mu 1$ containing $12.5 \mu 1$ of $2 \times$ PCR Master Mix with dye (0.1 U Taq Polymerase/ $\mu \mathrm{l}, 500 \mu \mathrm{M}$ dNTP each, $20 \mathrm{mM}$ Tris-HCl (pH 8.3), $100 \mathrm{mM} \mathrm{KCl}, 3 \mathrm{mM} \mathrm{MgCl} 2), 1 \mu \mathrm{l}$ of each primer, $9.5 \mu \mathrm{l}$ of double-distilled water and $1 \mu \mathrm{l}(100$ $500 \mathrm{ng}$ ) of DNA template.

PCR thermal cycler programs for all gene regions were programmed with an initial denaturation at $94{ }^{\circ} \mathrm{C}$ for $3 \mathrm{~min}$ and a final extension at $72{ }^{\circ} \mathrm{C}$ for $10 \mathrm{~min}$. ITS, LSU and tub2 gene amplifications were followed by 35 cycles of denaturation at $94{ }^{\circ} \mathrm{C}$ for 30 seconds, annealing at 55 ${ }^{\circ} \mathrm{C}$ for 50 seconds and extension at $72{ }^{\circ} \mathrm{C}$ for $1 \mathrm{~min}$. The PCR thermal cycles for SSU and tef 1 were followed by 35 cycles of denaturation at $95{ }^{\circ} \mathrm{C}$ for 45 seconds, annealing at $56{ }^{\circ} \mathrm{C}$ for 50 seconds and extension at $72{ }^{\circ} \mathrm{C}$ for $1 \mathrm{~min}$. All the PCR products were immediately subjected to $4{ }^{\circ} \mathrm{C}$ and were visualized on $1 \%$ agarose gel stained using Ethidium Bromide with D2000 DNA ladder (Realtimes Biotech, Beijing, China). PCR products were purified according to the company protocols and DNA sequencing was performed using the same primers in an Applied Biosystem 3730 DNA analyzer at Sangon Biotech (Shanghai) Co. Ltd., China.

\section{Phylogenetic analyses}

Verified sequences were used for BLAST analyses and related sequences were downloaded from the GenBank (https:/www.ncbi.nlm.nih.gov) following recent relevant publications (Wanasinghe et al. 2017a, Phukhamsakda et al. 2018) (Table 1). Individual loci were aligned using FFT-NS-2 Tree-based progressive method, 20PAM/ k=2 Scoring matrix for nucleotide sequences and 1.0 Gap opening penalty settings of MAFFT V.7.036 (http://mafft.cbrc.jp/alignment/server/) (Katoh et al. 2017) and improved when necessary in BioEdit v. 7.0 (Hall 2004) by manual adjustments. Characters were assessed to be unordered and equally weighted. MrModeltest 2.3 was performed for every single gene to estimate the best-fit evolutionary models under the Akaike Information Criterion (AIC) (Nylander 2004) and each resulted GTR $+\mathrm{I}+\mathrm{G}$ model. Phylogenies were generated using maximum parsimony (MP), maximum-likelihood (ML) and Bayesian inference (BI) analyses using combined LSU-SSU-ITS-tef1. All the newly generated sequences were deposited in GenBank for future studies.

MP analysis was carried out using PAUP v.4.0b 10 (Swofford 2002) with the heuristic search option and the number of replications 1,000 each. The tree length (TL), Consistency Indices (CI), Retention Indices (RI), Rescaled Consistency Indices (RC) and Homoplasy Index (HI) were documented. Kishino-Hasegawa tests (KHT) (Kishino \& Hasegawa 1989) were performed in order to determine whether trees were significantly different. ML analysis was performed with RAxMLGUI v.1.3 (Silvestro \& Michalak 2012) using the ML+rapid bootstrap setting with 1,000 replicates. The Bayesian tree (BI) was generated by using MCMC sampling in MrBayes v3.1.2 (Huelsenbeck \& Ronquist 2001, Zhaxybayeva \& Gogarten 2002) for 10,000,000 MCMC generations using four chains and partition analysis with 100 sample frequencies which products 100,000 trees. The suitable burn-in phases were determined by traces inspected in Tracer version 1.6 (Rambaut et al. 2014). The first 10,000 (10 \% from total) trees were the burn-in phase and were discarded based on tracer analysis. The remaining 90,000 trees were used to calculate the posterior probability in the majority rule consensus tree (when split frequency $<0.01$ ). The resulting trees were viewed with FigTree v.1.4.0 (Rambaut \& Drummond 2008) and the final layout was done with CorelDRAW Graphics Suite X6. The final alignment and tree were registered in TreeBASE under the submission ID: 25277 (http://www.treebase.org/). 
Table 1 Isolates used in this study and GenBank accession numbers.

\begin{tabular}{|c|c|c|c|c|c|c|}
\hline Taxon & Culture accession number(s) & LSU & SSU & ITS & tef1 & References \\
\hline Aquastroma magniostiolata & CBS 139680=MAFF 243824* & AB807510 & AB797220 & LC014540 & AB808486 & Tanaka et al. 2015 \\
\hline Aquilomyces patris & CBS $135661 *$ & KP184041 & KP184077 & KP184002 & N/A & Knapp et al. 2015 \\
\hline Aquilomyces rebunensis & CBS $139684^{*}$ & AB807542 & AB797252 & AB809630 & AB808518 & Tanaka et al. 2015 \\
\hline Bambusicola massarinia & MFLUCC 11-0389* & JX442037 & JX442041 & NR_121548 & N/A & Dai et al. 2012 \\
\hline Clypeoloculus akitaensis & CBS 139681* & AB807543 & AB797253 & AB809631 & AB808519 & Tanaka et al. 2015 \\
\hline Corynespora cassiicola & CBS $100822 *$ & GU301808 & GU296144 & N/A & GU349052 & Schoch et al. 2009 \\
\hline Corynespora smithii & CABI 5649b & GU323201 & N/A & FJ852597 & GU349018 & Schoch et al. 2009 \\
\hline Falciformispora lignatilis & BCC 21117 & GU371826 & GU371834 & KF432942 & GU371819 & Schoch et al. 2009 \\
\hline Falciformispora senegalensis & CBS $196.79 *$ & KF015631 & KF015636 & KF015673 & KF015687 & Ahmed et al. 2014 \\
\hline Falciformispora tompkinsii & CBS 200.79* & KF015625 & KF015639 & NR_132041 & KF015685 & Ahmed et al. 2014 \\
\hline Helicascus elaterascus & HKUCC 7769 & AY787934 & AF053727 & $\mathrm{N} / \mathrm{A}^{-}$ & N/A & Tanaka et al. 2015 \\
\hline Massarina eburnea & CBS 473.64 & GU301840 & GU296170 & N/A & GU349040 & Zhang et al. 2009 \\
\hline Monodictys sp. & KH 331=MAFF 243826 & AB807553 & AB797263 & N/A & AB808529 & Tanaka et al. 2015 \\
\hline Monodictys sp. & JO 10=MAFF 243825 & AB807552 & AB797262 & N/A & AB808528 & Tanaka et al. 2015 \\
\hline Morosphaeria ramunculicola & BCC 18404 & GQ925853 & GQ925838 & N/A & N/A & Suetrong et al. 2009 \\
\hline Morosphaeria velatispora & BCC 17059* & GQ925852 & GQ925841 & N/A & N/A & Suetrong et al. 2009 \\
\hline Multilocularia bambusae & MFLUCC 11-0180* & KU693438 & KU693442 & KU693446 & N/A & Li et al. 2016 \\
\hline Multiseptospora thailandica & MFLUCC 11-0183* & KP744490 & KP753955 & KP744447 & N/A & Liu et al. 2015 \\
\hline Multiseptospora thailandica & MFLUCC 11-0204 & KU693440 & KU693444 & KU693447 & KU705659 & Liu et al. 2015 \\
\hline Multiseptospora thailandica & MFLUCC 12-0006 & KU693441 & KU693445 & KU693448 & KU705660 & Liu et al. 2015 \\
\hline Multiseptospora thysanolaenae & MFLUCC 11-0238* & KU693439 & KU693443 & N/A & KU705658 & Li et al. 2016 \\
\hline Neoaquastroma bauhiniae & MFLUCC 16-0398* & MH023319 & MH023315 & MH025952 & MH028247 & Phukhamsakda et al. 2018 \\
\hline Neoaquastroma bauhiniae & MFLUCC 17-2205 & MH023320 & MH023316 & MH025953 & MH028248 & Phukhamsakda et al. 2018 \\
\hline Neoaquastroma cylindricum & MFLUCC 19-0489* & MN473054 & MN473048 & MN473060 & MN481600 & This study \\
\hline Neoaquastroma guttulatum & MFLUCC 14-0917* & KX949740 & KX949741 & KX949739 & KX949742 & Wanasinghe et al. 2017a \\
\hline Neoaquastroma krabiense & MFLUCC 16-0419* & MH023321 & MH023317 & MH025954 & MH028249 & Phukhamsakda et al. 2018 \\
\hline Palmiascoma gregariascomum & MFLUCC 11-0175* & KP744495 & KP753958 & KP744452 & N/A & Liu et al. 2015 \\
\hline Parabambusicola bambusina & KH 139=MAFF 243823 & AB807537 & AB797247 & LC014579 & AB808512 & Tanaka et al. 2015 \\
\hline Parabambusicola bambusina & H 4321=MAFF 239462 & AB807536 & AB797246 & LC014578 & AB808511 & Tanaka et al. 2015 \\
\hline Parabambusicola bambusina & KT 2637=MAFF 243822 & AB807538 & AB797248 & LC014580 & AB808513 & Tanaka et al. 2015 \\
\hline Pseudomonodictys tectonae & MFLUCC 12-0552 & KT285573 & KT285574 & N/A & KT285571 & Ariyawansa et al. 2015 \\
\hline Stagonospora pseudocaricis & CBS 135132 & KF251762 & N/A & KF251259 & N/A & Quaedvlieg et al. 2013 \\
\hline Trematosphaeria pertusa & CBS 122368* & FJ201990 & FJ201991 & NR_132040 & KF015701 & Zhang et al. 2008 \\
\hline
\end{tabular}

Types and authentic strains are indicated with *, newly generated sequences in this study are indicated in bold. "N/A" sequence is unavailable.

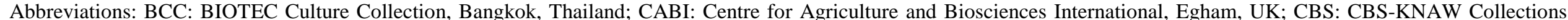

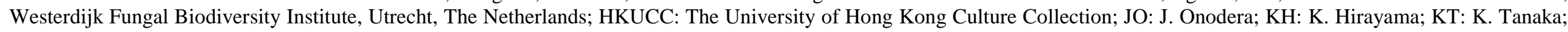
MAFF: Ministry of Agriculture, Forestry and Fisheries, Japan; MFLUCC: Mae Fah Luang University Culture Collection, Chiang Rai, Thailand. 


\section{Results}

Topology of phylogenetic analyses

The combined LSU-SSU-ITS-tef1 sequence matrix comprised of 33 taxa including the newly generated strain. Corynespora cassiicola (CBS 100822) and Corynespora smithii (CABI $5649 \mathrm{~b}$ ) were selected as outgroup taxa. The concatenated alignment comprised 3586 total characters including gaps (LSU: 1-880 bp, SSU: 881-1919 bp, ITS: 1920-2656 bp, tef1: 26573586 bp) with 1281 distinct alignment patterns and $23.17 \%$ proportion of gaps and completely undetermined characters, 2538 constant, 270 parsimony uninformative and 778 parsimony informative characters. The MP analysis resulted a single most parsimonious tree $(\mathrm{TL}=2706$, $\mathrm{CI}=0.572, \mathrm{RI}=0.679, \mathrm{RC}=0.388, \mathrm{HI}=0.428)$. The best $\mathrm{ML}$ phylogram (Fig. 1) $(\mathrm{InL}=-17995.951361$, $\alpha=0.474127$, invar $=0.473346$ ) resulted with estimated base frequencies $\mathrm{A}=0.238, \mathrm{C}=0.251$, $\mathrm{G}=0.274, \mathrm{~T}=0.237$, substitution rates $\mathrm{AC}=1.023629, \mathrm{AG}=2.050054, \mathrm{AT}=1.180510, \mathrm{CG}=0.891203$, $\mathrm{CT}=5.263957, \mathrm{GT}=1.0000$, proportion of variable sites and gamma distribution shape parameter. The tree topologies resulted from ML, MP and BI analyses are similar.

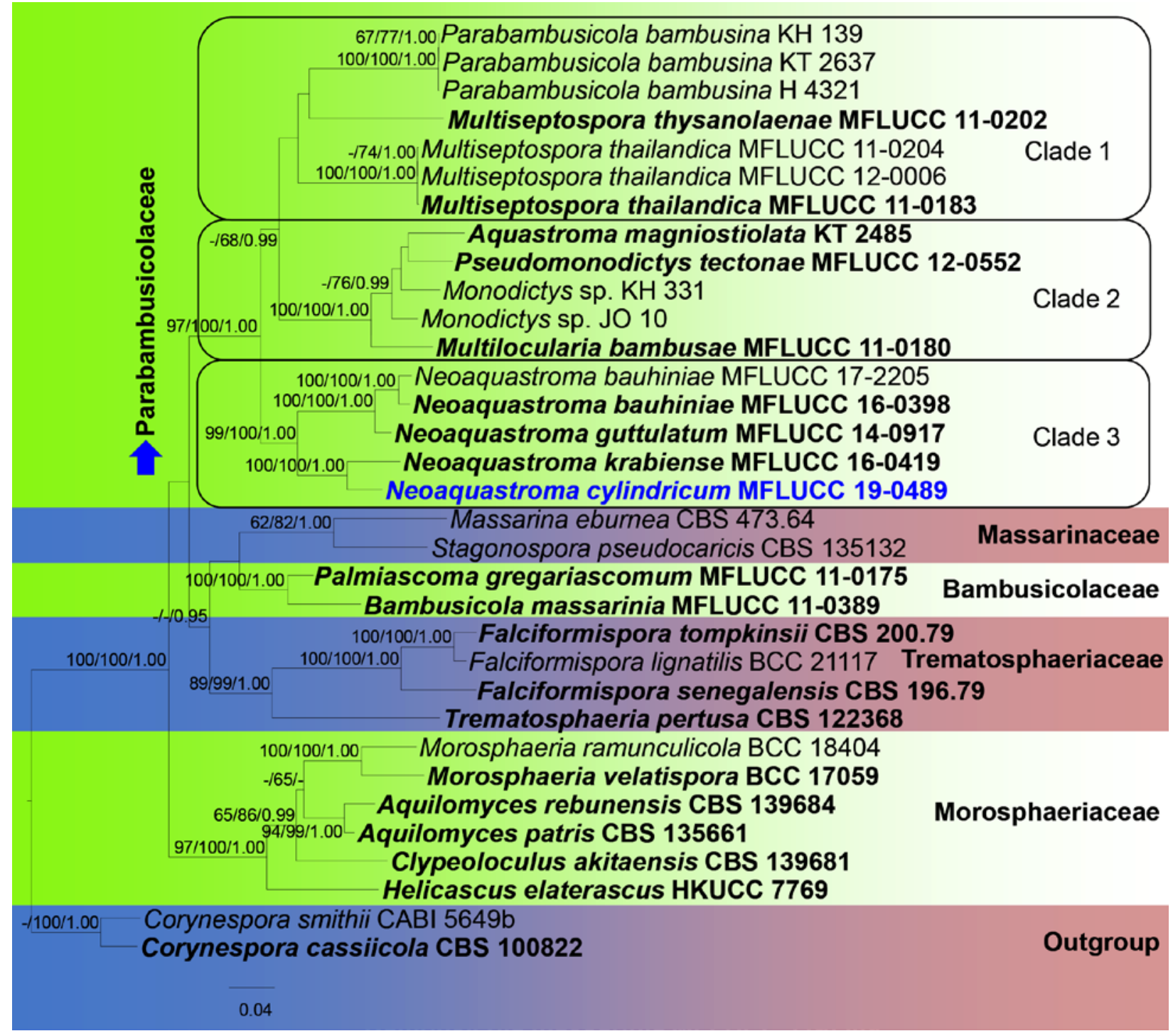

Fig. 1 - Phylogram generated from maximum likelihood (RAxML) based on LSU-SSU-ITS-tef1 matrix. The tree is rooted in Corynespora cassiicola (CBS 100822) and Corynespora smithii (CABI 5649b). MP, ML bootstrap supports $(\geq 60 \%)$ and BI posterior probabilities $(\geq 0.95 \mathrm{PP})$ supports are given above or below the branches respectively. Type strains are in bold and the newly introduced taxon is in blue. 
Genera belong to Parabambusicolaceae clustered in three distinct sub-clades as 1, 2 and 3 (Fig. 1). Clade 1 comprises Parabambusicola bambusina, the generic type and two species of Multiseptospora. Those two species of Multiseptospora (M. thailandica, M. thysanolaenae) are not monophyletic within clade 1. Clade 2 comprises Aquastroma, Multilocularia, Pseudomonodictys and two 'Monodictys' strains (68 \% ML/0.99 PP BI). Clade 3 comprises Neoaquastroma species as a monophyletic group basal to clade 1 and 2 with strong statistical support (97\% MP/100\% ML/1.00 PP BI). Our strain MFLUCC 19-0489 clusters together with N. krabiense (MFLUCC 160419) with high statistical support (100\% MP/100 \% ML/1.00 PP BI), but represents a distinct lineage.

In BLASTn searches on NCBI GenBank, the closest matches of our sequences are Neoaquastroma. The ITS sequence is $95 \%$ similar to $N$. krabiense (MFLUCC 16-0419) while tef1 is similar to $N$. krabiense (MFLUCC 16-0419; 97 \%), N. guttulatum (MFLUCC 14-0917; 96 \%) and $N$. bauhiniae (MFLUCC 17-2205; $95 \%$ ). However, LSU sequence is $95 \%$ similar to Monodictys sp. (KH 331) and $95 \%$ similar to N. bauhiniae (MFLUCC 17-2205).

\section{Taxonomy}

Neoaquastroma cylindricum Samarak. \& K.D. Hyde, sp. nov.

Index Fungorum number: IF556820; Facesoffungi number: FoF06520

Etymology - the epithet "cylindricum” referring to cylindric-clavate asci

Holotype - MFLU 19-2110

Saprobic on dead twigs. Sexual morph Ascomata 175-220 $\mu \mathrm{m}$ high $\times 150-250 \mu \mathrm{m}$ diam. $(\bar{x}=$ $200 \times 220 \mu m, \mathrm{n}=10$ ), immersed in the bark, solitary, scattered or sometimes gregarious, compressed globose, sub-globose, with a flattened base, black to dark brown, smooth, papillate, ostiolate. Ostiole 125-135 $\mu \mathrm{m}$ high $\times 60-75 \mu \mathrm{m}$ diam. $(\bar{x}=132 \times 64 \mu \mathrm{m}, \mathrm{n}=10)$, centrally located, oblong, filled with hyaline cells. Peridium $10-25 \mu \mathrm{m}(\bar{x}=19 \mu \mathrm{m}, \mathrm{n}=10)$ wide, comprising 2 layers, outer layer pigmented, comprising reddish to dark brown, fused with host tissues, thinwalled cells of textura angularis, inner layer composed of hyaline, loosen, cells of textura angularis. Hamathecium composed of numerous, dense, long, 1.2-2.3 $\mu \mathrm{m}(\bar{x}=1.7 \mu \mathrm{m}, \mathrm{n}=35)$, filamentous, branched, septate, pseudoparaphyses. Asci 80-115 $\times 14-18 \mu \mathrm{m}(\overline{\mathrm{x}}=91.5 \times 15.6 \mu \mathrm{m}, \mathrm{n}$ $=25$ ), 8-spored, bitunicate, fissitunicate, cylindric-clavate, with a short pedicel, apically rounded with broad ocular chamber. Ascospores 20-27 ×5-6.5 $\mu \mathrm{m}(\overline{\mathrm{x}}=24.5 \times 5.7 \mu \mathrm{m}, \mathrm{n}=35)$, overlapping biseriate, ellipsoidal to sub-fusiform, hyaline, 3-5-transversely septate at maturity, with the primary septum almost median, deeply constricted at the middle septum, constricted at remaining septa, slightly curved, rough-walled, 1-2 prominent guttules in each cell, lacking guttules when over mature, ends remaining cone-shaped, with pointed ends, upper part larger than lower part, surrounded by a 3.7-7.6 $\mu \mathrm{m}(\overline{\mathrm{x}}=5.3 \mu \mathrm{m}, \mathrm{n}=10)$, distinct mucilaginous sheath. Asexual morph: Undetermined.

Culture characteristics - Colonies on PDA, reaching $30 \mathrm{~mm}$ diam. after three weeks at $25{ }^{\circ} \mathrm{C}$. Culture grey, becoming dark-olive brown after three weeks, of dense mycelia, colonies circular, flat, umbonate, raised from the agar in the center, surface rough, dull, covered with aerial mycelium, white mycelium radiating into the agar, pale orange pigment diffusing in the agar from the top view; reverse black, dense, circular, with irregular, fimbriate margin.

Material examined - China, Guizhou, Guiyang, Guizhou Academy of Agricultural Sciences (GZAAS), on dead twigs, 22 July 2018, M.C. Samarakoon, SAMC171 (MFLU 19-2110, holotype; HKAS 102399, isotype) - ex-type living culture MFLUCC 19-0489. Additional sequence: MN481604 (tub2).

\section{Discussion}

In this study, we introduced Neoaquastroma cylindricum isolated from the bark of dead twigs as the first record from China in this genus. The morphological characterization of our new taxon is close affinity to the genus Neoaquastroma in having globose to sub-globose ascomata, reddish to 
dark brown outer layer and hyaline inner layer peridium, transversely septate ascospores with large guttules and surrounded by a large mucilaginous sheath (Wanasinghe et al. 2017a). However, $N$. cylindricum differs from other Neoaquastroma species in having cylindric-clavate asci with comparatively small ascospores $(20-27 \times 5-6.5 \mu \mathrm{m})$ that are having 3-5-transversely septa (Table 2). In addition, $N$. bauhiniae and $N$. krabiense possess a wider cell above central septum of the ascospores which is not noticeable in our species (Phukhamsakda et al. 2018).

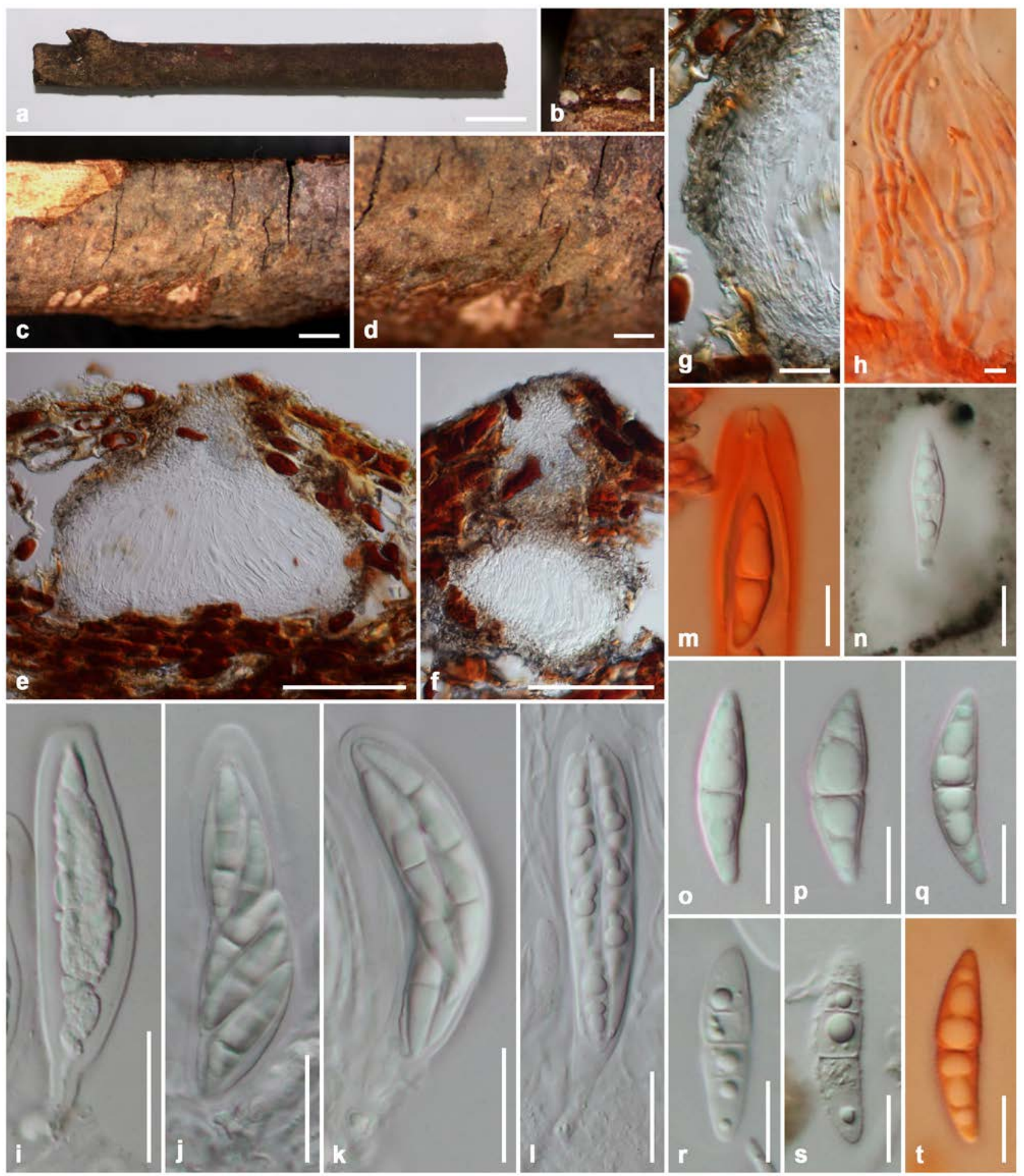

Fig. 2 - Neoaquastroma cylindricum (holotype, MFLU 19-2110). a-d Ascomata on the substrate. e, f Vertical section of ascoma. g Peridium. h Paraphyses. i-l Asci. m Ocular chamber (in Congo Red). $n$-t Ascospores ( $\mathrm{n}$ in Indian ink, $\mathrm{t}$ in Congo Red). Scale bars: $\mathrm{a}=1 \mathrm{~cm}, \mathrm{c}=1000 \mu \mathrm{m}, \mathrm{b}, \mathrm{d}=500$ $\mu \mathrm{m}, \mathrm{g}, \mathrm{i}-\mathrm{l}=20 \mu \mathrm{m}, \mathrm{h}, \mathrm{m}-\mathrm{t}=10 \mu \mathrm{m}$. 
Phylogenetic trees obtained from MP, ML and BI analyses were similar in overall topology as previous studies (Wanasinghe et al. 2017a, Phukhamsakda et al. 2018). In clade 3, Neoaquastroma cylindricum and $N$. krabiense constitute a basal sister-clade to other Neoaquastroma species. In a comparison of the ITS (+5.8S) nucleotides of these two strains reveals 49 (8.9 \%) nucleotide differences including gaps. Both morph-molecular differentiations justify these two isolates as two distinct taxa (Jeewon \& Hyde 2016).

It is worth pointing out that the affinities of the two Multiseptospora species are obscure given that there is no reliable support for clade 1 (Fig. 1). This is not a common phenomenon in contrast to those phylogenetic lineages to the remaining taxa in this family. Further taxon sampling with molecular work should be established to resolve the exact classification of Multiseptospora species.

Table 2 Synopsis of Neoaquastroma species.

\begin{tabular}{|c|c|c|c|c|c|c|}
\hline Species & Substrate & Country & $\begin{array}{l}\text { Ascomata } \\
(\mu \mathrm{m})\end{array}$ & $\begin{array}{l}\text { Asci } \\
(\mu \mathrm{m})\end{array}$ & $\begin{array}{l}\text { Ascospores } \\
(\mu \mathrm{m})\end{array}$ & Reference \\
\hline N. bauhiniae & $\begin{array}{l}\text { dead twigs, } \\
\text { Bauhinia } \\
\text { variegata } \\
\text { (Fabaceae) }\end{array}$ & Thailand & $\begin{array}{l}113-190 \times 170-307 \\
\text { semi-immersed to } \\
\text { immersed }\end{array}$ & $\begin{array}{l}53-116 \times 26-43, \\
\text { oboviod to oblong }\end{array}$ & $\begin{array}{l}\text { 37-46 × 9-16 } \\
\text { 4-7-transversely } \\
\text { septate }\end{array}$ & $\begin{array}{l}\text { Phukhamsakda } \\
\text { et al. (2018) }\end{array}$ \\
\hline N. cylindricum & dead twigs & China & $\begin{array}{l}175-220 \times 150-250 \\
\text { immersed }\end{array}$ & $\begin{array}{l}80-115 \times 14-18 \\
\text { cylindric-clavate }\end{array}$ & $\begin{array}{l}\text { 20-27 × 5-6.5 } \\
\text { 3-5-transversely } \\
\text { septate }\end{array}$ & This study \\
\hline N. guttulatum & dead twigs & Thailand & $\begin{array}{l}240-280 \times 210-250 \\
\text { immersed }\end{array}$ & $\begin{array}{l}90-140 \times 30-40 \\
\text { clavate }\end{array}$ & $\begin{array}{l}35-50 \times 11-15 \\
3-7-t r a n s v e r s e l y \\
\text { septate }\end{array}$ & $\begin{array}{l}\text { Wanasinghe et } \\
\text { al. (2017a) }\end{array}$ \\
\hline N. krabiense & $\begin{array}{l}\text { dead twigs, } \\
\text { Barringtonia } \\
\text { acutangula } \\
\text { (Lecythidaceae) }\end{array}$ & Thailand & $\begin{array}{l}404-498 \times 290-319 \\
\text { immersed }\end{array}$ & $\begin{array}{l}95-169 \times 29-45 \\
\text { oboviod to clavate }\end{array}$ & $\begin{array}{l}\text { 50-64 × 9-18 } \\
\text { 5-8-transversely } \\
\text { septate }\end{array}$ & $\begin{array}{l}\text { Phukhamsakda } \\
\text { et al. (2018) }\end{array}$ \\
\hline
\end{tabular}

\section{Acknowledgement}

Milan C. Samarakoon is grateful to the Mushroom Research Foundation (MRF), Chiang Rai, Thailand. Dr. Shaun Pennycook is thanked for the nomenclatural advice. Jian Kui Liu thanks the National Natural Science Foundation of China (NSFC 31600032) and Science and Technology Foundation of Guizhou Province (LH [2015]7061). Dhanushka Wanasinghe would like to thank CAS President's International Fellowship Initiative (PIFI) for funding his postdoctoral research (number 2019PC0008) and the National Science Foundation of China and the Chinese Academy of Sciences for financial support under the following grants: 41761144055, 41771063 and Y4ZK111B01. This research work was partially supported by Chiang Mai University.

\section{References}

Ahmed SA, Van De Sande WW, Stevens DA, Fahal A et al. 2014 - Revision of agents of blackgrain eumycetoma in the order Pleosporales. Persoonia 33, 141-154.

Ariyawansa HA, Hyde KD, Jayasiri SC, Buyck B et al. 2015 - Fungal diversity notes 111-252taxonomic and phylogenetic contributions to fungal taxa. Fungal Diversity 75, 27-274.

Carbone I, Kohn LM. 1999 - A method for designing primer sets for speciation studies in filamentous ascomycetes. Mycologia 91, 553-556.

Chomnunti P, Hongsanan S, Aguirre-Hudson B, Tian Q et al. 2014 - The sooty moulds. Fungal Diversity 66, 1-36.

Crous PW, Schumacher RK, Akulov A, Thangavel R et al. 2019 - New and Interesting Fungi 2. Fungal Systematics and Evolution 3, 57-134.

Crous PW, Schumacher RK, Wingfield MJ, Akulov A et al. 2018 - New and Interesting Fungi 1. Fungal Systematics and Evolution 1, 169-215. 
Dai DQ, Bhat DJ, Liu JK, Chukeatirote E et al. 2012 - Bambusicola, a new genus from bamboo with asexual and sexual morphs. Cryptogamie Mycologie 33, 363-379.

Glass NL, Donaldson GC. 1995 - Development of primer sets designed for use with the PCR to amplify conserved genes from filamentous ascomycetes. Applied and Environmental Microbiology 61, 1323-1330.

Hall TA. 2004 - BioEdit Sequence Alignment Editor 7.0. 1. Carlsbad, CA, USA: Isis Pharmaceuticals.

Huelsenbeck JP, Ronquist F. 2001 - MRBAYES: Bayesian inference of phylogenetic trees. Bioinformatics 17, 754-755.

Hyde KD, Chaiwan N, Norphanphoun C, Boonmee S et al. 2018 - Mycosphere notes 169-224. Mycosphere 9, 271-430.

Hyde KD, Hongsanan S, Jeewon R, Bhat DJ et al. 2016 - Fungal diversity notes 367-490: taxonomic and phylogenetic contributions to fungal taxa. Fungal Diversity 80, 1-270.

Hyde KD, Norphanphoun C, Abreu VP, Bazzicalupo A et al. 2017 - Fungal diversity notes 603708: taxonomic and phylogenetic notes on genera and species. Fungal Diversity 87, 1-235.

Hyde KD, Tennakoon DS, Jeewon R, Bhat DJ et al. 2019 - Fungal diversity notes 1036-1150: taxonomic and phylogenetic contributions on genera and species of fungal taxa. Fungal Diversity 96, 1-242.

Jayasiri SC, Hyde KD, Ariyawansa HA, Bhat J et al. 2015 - The Faces of Fungi database: fungal names linked with morphology, phylogeny and human impacts. Fungal Diversity 74, 3-18.

Jeewon R, Hyde KD. 2016 - Establishing species boundaries and new taxa among fungi: recommendations to resolve taxonomic ambiguities. Mycosphere 7, 1669-1677.

Katoh K, Rozewicki J, Yamada KD. 2017 - MAFFT online service: multiple sequence alignment, interactive sequence choice and visualization. Briefings in bioinformatics bbx108.

Kishino H, Hasegawa M. 1989 - Evaluation of the maximum likelihood estimate of the evolutionary tree topologies from DNA sequence data, and the branching order in Hominoidea. Journal of Molecular Evolution 29, 170-179.

Knapp DG, Kovács GM, Zajta E, Groenewald JZ, Crous PW. 2015 - Dark septate endophytic pleosporalean genera from semiarid areas. Persoonia 35, 87-100.

Li GJ, Hyde KD, Zhao RL, Hongsanan S et al. 2016 - Fungal diversity notes 253-366: taxonomic and phylogenetic contributions to fungal taxa. Fungal Diversity 78, 1-237.

Liu JK, Hyde KD, Jeewon R, Phillips AJL et al. 2017 - Ranking higher taxa using divergence times: a case study in Dothideomycetes. Fungal Diversity 84, 75-99.

Liu JK, Hyde KD, Jones EG, Ariyawansa HA et al. 2015 - Fungal Diversity Notes 1-110: Taxonomic and phylogenetic contributions to fungal species. Fungal Diversity 72, 1-197.

Nylander JAA. 2004 - MrModeltest v2 Program distributed by the author. Evolutionary Biology Centre, Uppsala University.

Phookamsak R, Hyde KD, Jeewon R, Bhat DJ et al. 2019 - Fungal diversity notes 929-1035: taxonomic and phylogenetic contributions on genera and species of fungi. Fungal Diversity 95, 1-273.

Phukhamsakda C, Bhat DJ, Hongsanan S, Xu JC et al. 2018 - Two novel species of Neoaquastroma (Parabambusicolaceae, Pleosporales) with their phoma-like asexual morphs. MycoKeys 34, 47-62.

Quaedvlieg W, Verkley GJ, Shin HD, Barreto RW et al. 2013 - Sizing up Septoria. Studies in Mycology 75, 307-339.

Rambaut A, Drummond A. 2008 - FigTree: Tree figure drawing tool, version 122 Institute of Evolutionary Biology, University of Edinburgh.

Rambaut A, Suchard MA, Xie D, Drummond AJ. 2014 - Tracer v16, Available from http://beast.bio.ed.ac.uk/Tracer.

Samarakoon MC, Gafforov Y, Liu N, Maharachchikumbura SSN et al. 2018 - Combined multigene backbone tree for the genus Coniochaeta with two new species from Uzbekistan. Phytotaxa 336, 043-058. 
Schoch CL, Crous PW, Groenewald JZ, Boehm EW et al. 2009 - A class-wide phylogenetic assessment of Dothideomycetes. Studies in Mycology 64, 1-15.

Silvestro D, Michalak I. 2012 - raxmlGUI: a graphical front-end for RAxML. Organisms Diversity \& Evolution 12, 335-337.

Suetrong S, Schoch CL, Spatafora JW, Kohlmeyer J et al. 2009 - Molecular systematics of the marine Dothideomycetes. Studies in Mycology 64, 155-173.

Swofford DL. 2002 - PAUP*: phylogenetic analysis using parsimony (* and other methods) Sunderland, MA.

Tanaka K, Hirayama K, Yonezawa H, Sato G et al. 2015 - Revision of the Massarineae (Pleosporales, Dothideomycetes). Studies in Mycology 82, 75-136.

Vilgalys R, Hester M. 1990 - Rapid genetic identification and mapping of enzymatically amplified ribosomal DNA from several Cryptococcus species. Journal of Bacteriology 172, 4238-4246.

Wanasinghe DN, Hyde KD, Konta S, To-Anun C et al. 2017a - Saprobic Dothideomycetes in Thailand: Neoaquastroma gen. nov. (Parabambusicolaceae) introduced based on morphological and molecular data. Phytotaxa 302, 133-144.

Wanasinghe DN, Jeewon R, Tibpromma S, Jones EBG et al. 2017b - Saprobic Dothideomycetes in Thailand: Muritestudina gen. et sp. nov. (Testudinaceae) a new terrestrial pleosporalean ascomycete, with hyaline and muriform ascospores. Studies in Fungi 2, 219-234.

Wanasinghe DN, Phukhamsakda C, Hyde KD, Jeewon R et al. 2018 - Fungal diversity notes 709839: taxonomic and phylogenetic contributions to fungal taxa with an emphasis on fungi on Rosaceae. Fungal Diversity 89, 1-236.

White TJ, Bruns T, Lee SJ, Taylor JW. 1990 - Amplification and direct sequencing of fungal ribosomal RNA genes for phylogenetics. PCR protocols: a guide to methods and applications 18, 315-322.

Wijayawardene NN, Hyde KD, Lumbsch HT, Liu JK et al. 2018 - Outline of Ascomycota: 2017. Fungal Diversity 88, 167-263.

Wijayawardene NN, Hyde KD, Rajeshkumar KC, Hawksworth DL et al. 2017 - Notes for generaAscomycota. Fungal Diversity 86, 1-594.

Willis KJ. 2018 - State of the World’s Fungi 2018. Report. Royal Botanic Gardens, Kew.

Zhang Y, Fournier J, Pointing SB, Hyde KD. 2008 - Are Melanomma pulvis-pyrius and Trematosphaeria pertusa congeneric?. Fungal Diversity 33, 47-60.

Zhang Y, Wang HK, Fournier J, Crous PW et al. 2009 - Towards a phylogenetic clarification of Lophiostoma/Massarina and morphologically similar genera in the Pleosporales. Fungal Diversity 38, 225-251.

Zhaxybayeva O, Gogarten JP. 2002 - Bootstrap, Bayesian probability and maximum likelihood mapping: exploring new tools for comparative genome analyses. BMC genomics 3, 1-4. 